\title{
Seasonal variation in abundance and feeding rates of the first stages of copepods in a temperate sea
}

\author{
Eva López*, Leticia Viesca, Ricardo Anadón \\ Área de Ecología, Departamento de Biología de Organismos y Sistemas, Universidad de Oviedo, C/ Catedrático Rodrigo \\ Uría, s/n, CP 33071, Oviedo, Spain
}

\begin{abstract}
An understanding of the role of copepod populations in marine ecosystems and carbon fluxes is limited by the scarcity of information on small copepods and developmental stages (nauplii and copepodites). Here, we present a study that includes the whole copepod population in the Cantabrian Sea, with special emphasis on copepodites and copepods <200 $\mu \mathrm{m}$ and nauplii. Total copepod abundance and feeding rates of phytoplankton by nauplii, copepods and copepodites belonging to the size fraction $<200 \mu \mathrm{m}$ were measured during an annual cycle in 3 stations off Cudillero (southern Bay of Biscay). Nauplii were the most abundant group in the metazooplankton, with densities ranging between 1 and 48 ind. $1^{-1}$. The highest abundances were found during late summer and autumn. Feeding rates on phytoplankton showed a significant increase with chlorophyll a concentration in the water, and a saturation response at around $240 \mu \mathrm{g} \mathrm{C} \mathrm{l}^{-1}$. Specific ingestion rates

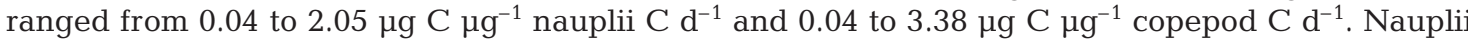
and copepods $<200 \mu \mathrm{m}$, respectively, ingested 0.2 to $7.1 \%$ and 0.1 to $4.9 \%$ of total chlorophyll $a$ in the water column daily.
\end{abstract}

KEY WORDS: Copepod nauplii · Ingestion rates $\cdot$ Gut fluorescence $\cdot$ Cantabrian Sea

Resale or republication not permitted without written consent of the publisher

\section{INTRODUCTION}

In the present scenario of general concern about climate change, the need to understand the biogeochemical cycles in the oceans and quantify the importance of all processes taking part in them is becoming increasingly important. Research programs on this topic are mostly focused on coastal zones due to their accessibility and special characteristics: they are generally very sensitive to any external forcing, so climate change is likely to have the greatest impact on them, and they are likely to be the first regions to experience the resultant effects (Sündermann et al. 2001). Therefore, it is essential to cover a wide spectrum of variables in coastal research programs to establish an observation strategy and to develop prediction models.

Monthly sampling has been conducted in the central Cantabrian Sea (north of Spain) since 1993. During this period, several studies related to long-term changes in environmental conditions (e.g. Llope et al. 2006) have been carried out in this area. In addition, studies have investigated the abundance and feeding impact of different taxonomical groups, such as fish larvae (González-Quirós \& Anadón 2001), appendicularians (López-Urrutia et al. 2003), mesozooplanktonic copepods (Huskin et al. 2006), protozoa (Quevedo \& Anadón 2000) and bacteria (González et al. 2003). A great deal of information is available about most of the main zooplanktonic groups in the area, the major deficiency being the lack of studies on small copepods and nauplii.

Copepods are the most abundant group in the metazooplankton and have been one of the main foci of oceanographic studies in recent decades. There is a significant amount of information about mesozooplanktonic copepod abundance in the Cantabrian Sea, e.g. Huskin et al. (2006), who also evaluated copepod feeding rates in our study area during an annual cycle. However, previous studies have not included the microzooplanktonic fraction of copepods. Microzooplankton are composed of Protozoa and Metazoa (mostly nauplii and copepodites), the former of which 
are usually more abundant, composed of smaller sizes, and have higher specific rates than micrometazoa. The dilution technique described by Landry \& Hassett (1982) has been widely used in the past 2 decades to estimate microzooplankton grazing impacts on primary production. It provides an estimate for the entire community, but, due to physiological differences between Protozoa and Metazoa, it is not possible to assume that all grazers contribute equally to the total grazing effect, so this approach does not allow us to estimate individual feeding rates of microzooplanktonic copepods. In addition, the use of this technique would be limited in ecosystems where nauplii, copepodites and small copepod densities are too low to be adequately represented in experimental bottles, such as oligotrophic regions and most temperate areas during certain periods in the annual cycle (as occurs in the Cantabrian Sea). In these cases, a better approach would be to perform dilution experiments with a smaller size fraction to remove the largest micrometazoa, and to assess nauplii and small copepod feeding rates using a different technique.

Studies of feeding rates for the naupliar phase are very scarce (López et al. 2007), and most of the published data are from laboratory studies using cultures of copepods and phytoplankton, which are difficult to extrapolate to natural conditions. To our knowledge, there are no studies in the literature dealing with the seasonal changes in nauplii feeding rates. Nauplii have received little attention despite the fact that they are more abundant than copepodites and copepods in the field, and that their success in the plankton community will ultimately determine recruitment into the copepodite phase and, consequently, affect plankton population dynamics (Torres \& Escribano 2003). Although studies investigating the abundance of small copepods and nauplii are more numerous than feeding studies (Turner 2004), data are still relatively scarce due to the common use of $200 \mu \mathrm{m}$ mesh nets in mesozooplankton sampling. The bias produced by the use of such large pore-sized nets to sample copepod assemblages has been reported in a number of studies (e.g. Calbet et al. 2001, Turner 2004). The consequent lack of information on the smaller sized fraction of the community (developmental stages and small copepods) prevents an adequate evaluation of their importance in the oceanic carbon cycle.

The scarcity of data on nauplii feeding rates in natural communities is a result of the methodological difficulty in manipulating these small organisms in the field. In a previous study (López et al. 2007), the gut fluorescence technique (Mackas \& Bohrer 1976) was further developed so it could be applied to small metazoans, and it was used in the present work to measure nauplii ingestion rates on phytoplankton.
In this study, ingestion rates of nauplii, copepods and copepodites from the $<200 \mu \mathrm{m}$ size fraction were measured over an annual cycle. The functional responses of these groups were studied, and the feeding impact on phytoplankton was evaluated and compared to data obtained for larger copepods by Huskin et al. (2006). Seasonal changes in abundance were also determined and related to phytoplankton concentration and water temperature.

\section{MATERIALS AND METHODS}

The study took place on a transect comprising 3 stations (Stns E1, E2 and E3) off Cudillero in the southern Bay of Biscay (Fig. 1). This zone exhibits a very dynamic hydrography (described by Llope et al. 2006), and the stations show significant differences despite their proximity. Stn E1 (65 m depth) is a coastal station influenced by freshwater discharges, tidal currents and frequent wind-driven upwelling during summer. Stn E2 (130 m depth) is located on the continental shelf and is also affected by upwelling events, as well as the Iberian Poleward Current (IPC). Stn E3 (850 m depth) is located on the slope and is only marginally affected by upwelling, probably by offshore advection (Stenseth et al. 2006), and the IPC during autumn and winter.

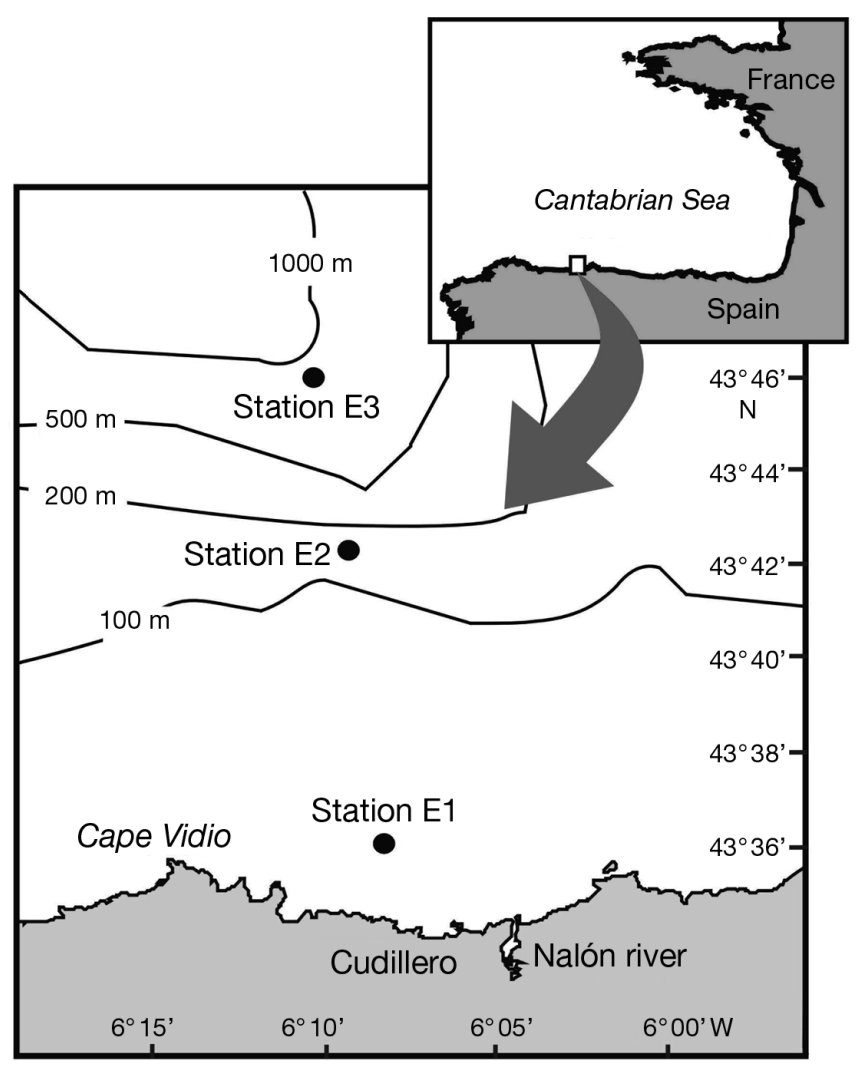

Fig. 1. Location of sampling stations 
Monthly sampling was carried out in 2003. Vertical profiles of temperature and salinity were carried out at Stns E1, E2 and E3 from depths of 50, 100 and $500 \mathrm{~m}$, respectively, using a SeaBIRD25 CTD. Water samples were taken from a rosette equipped with 51 Niskin bottles for phytoplankton counting and primary production (Stn E2) and to determine chlorophyll (chl) a concentration (Stns E1, E2 and E3).

Chl a concentration was determined fluorometrically. Water samples were collected at 6 to 10 different depths from the surface to the bottom of the photic layer. Samples were carried to the laboratory under cold conditions and filtered onto GF-F filters. Filters were frozen and extracted in $5 \mathrm{ml} 90 \%$ acetone during $24 \mathrm{~h}$ in the dark and cold. Chl a concentration was measured with a Turner Designs 10 fluorometer following the method of Yentsch \& Menzel (1963).

Primary production was determined by incubating water from 3 different depths (surface, chlorophyll $a$ (chl a) maximum and limit of the photic layer) with ${ }^{14} \mathrm{C}$. Water samples were inoculated with $370 \mathrm{kBq}(10 \mu \mathrm{Ci}$ $\mathrm{NaH}^{14} \mathrm{CO}_{3}$ ) and incubated for $2 \mathrm{~h}$. Three light bottles and 1 dark bottle (control) were incubated for each depth. Temperature and light for each treatment were simulated following preliminary study of the CTD casts. After incubation, samples were filtered onto GF-F filters, exposed for $12 \mathrm{~h}$ to concentrated $\mathrm{HCl}$ fumes to remove inorganic ${ }^{14} \mathrm{C}$, and counted in a WALLAC 1409 scintillation counter. Quenching was corrected by the internal standard method. Primary production could not be measured in August due to technical problems.

Water samples for phytoplankton species identification were collected at 3 different depths at Stn E2 (surface, chl a maximum and photic boundary layer) and preserved using $2 \%$ final concentration Lugol's iodine solution. Subsamples $(100 \mathrm{ml})$ were settled (Utermöhl method) and counted under an inverted microscope.

At each station, $1 \mathrm{WP}-2$ net $(37 \mathrm{~cm}$ diameter, $200 \mu \mathrm{m}$ mesh) was deployed to 50, 100 or $200 \mathrm{~m}$ at Stns E1, E2 and E3, respectively, for mesozooplankton biomass quantification. The contents of each cod end were transferred into $250 \mathrm{ml}$ plastic bottles and brought to the laboratory where they were screened through 200, 500 and $1000 \mu \mathrm{m}$ mesh sieves to create 3 size fractions. Each fraction was filtered onto GF-A pre-combusted and pre-weighed filters, maintained for $48 \mathrm{~h}$ at $60^{\circ} \mathrm{C}$ and weighed. Biomass was expressed as $\mathrm{mg}$ dry weight $\mathrm{m}^{-3}$.

Two net tows were carried out at each station using a $53 \mu \mathrm{m}$ mesh net to collect zooplankton from the upper $50 \mathrm{~m}$. The first net tow was devoted to metazooplankton taxonomic composition and the second to gut fluorescence analysis. A few net samples were lost in October, November and December. The first net sample haul was screened through 200 and $30 \mu \mathrm{m}$ meshes, and both samples were fixed using $4 \%$ buffered formaldehyde. Organisms were determined under a stereomicroscope to the level of main taxonomic group. The second net haul sample was fractionated in the same way, and samples from the $<200 \mu \mathrm{m}$ size fraction were filtered onto mesh filters, frozen in liquid nitrogen and kept frozen until further analysis. Gut fluorescence was measured for nauplii and copepods $<200 \mu \mathrm{m}$ (cop $<200 \mu \mathrm{m}$, includes copepodites and copepods from the $<200 \mu \mathrm{m}$ size fraction, as we did not distinguish between them) following the method of Mackas \& Bohrer (1976) adapted for small metazoans by López et al. (2007). For each station, 3 groups of 20 nauplii and 6 groups of $10 \mathrm{cop}<200 \mu \mathrm{m}$ were analysed. The samples were extracted in $120 \mu \mathrm{l}$ of acetone $(90 \%)$ for $24 \mathrm{~h}$ at $4{ }^{\circ} \mathrm{C}$ and measured with a Turner Designs 700 fluorometer with a minicell adapter kit.

Ingestion rates $(I)$ were calculated with the formula:

$$
I=k G
$$

where $k$ is the gut clearance coefficient and $G$ is gut content (expressed as ng chl a equiv. ind ${ }^{-1}$ ).

The gut clearance coefficient $(k)$ was estimated using the empirical relationship with temperature $(T)$ proposed by Dam \& Peterson (1988) for adult copepods:

$$
k=0.0117+0.0018 T
$$

A previous study looking at copepod nauplii (López et al. 2007) found no significant differences between gut evacuation rates obtained for nauplii in the laboratory and rates estimated using Eq. (2).

Photographs were taken under the stereomicroscope of at least 40 nauplii and $40 \mathrm{cop}<200 \mu \mathrm{m}$ from every sample. Image-Pro Plus software was used to measure total body length for nauplii and prosome length for cop $<200 \mu \mathrm{m}$. Dry weight was estimated following the empirical relationships:

$$
\begin{gathered}
\text { Log dry weight }(\mu \mathrm{g}) \\
=2.1034 \log \text { nauplii total length }(\mu \mathrm{m})-5.2105 \\
\text { Log dry weight }(\mu \mathrm{g})=2.6757 \mathrm{log} \\
\text { copepodite prosome length }(\mu \mathrm{m})-6.7625
\end{gathered}
$$

The relationships from Eqs. (3) and (4) were calculated with data from Klein Breteler et al. (1982) of 4 species of copepods that are very abundant in our study area. Their graphs were scanned and data were extracted with Image-Pro Plus software; new relationships were calculated by plotting all the data together. Parameters obtained were in the same range as most empirical relationships presented by Mauchline (1998), usually obtained for only one species of copepod. 
Given that an index to convert chl a concentration into $\mathrm{C}$ units was not available for each station and date of sampling, a value of 50 was used for all samples (Taylor et al. 1997).

Equations for the different types of functional responses (Holling 1965) were fitted by applying the least-squares criterion to the ingestion data. For the Type I fit (rectilinear model) we followed the procedure of Rothhaupt (1990) to calculate the deflection point, and then we obtained the fit for the combination of 2 linear regressions:

$$
\begin{aligned}
& I=a C \text {, when } C \leq C_{\mathrm{d}} \\
& I=I_{\max } \text {, when } C>C_{\mathrm{d}}
\end{aligned}
$$

where $I$ is specific ingestion rate $\left(\mu \mathrm{g} \mathrm{C} \mu \mathrm{g}^{-1}\right.$ nauplii $\mathrm{C} \mathrm{d}^{-1}$ ), $a$ is a constant, $C$ is phytoplankton concentration ( $\left.\mathrm{mg} \mathrm{chl} \mathrm{a} \mathrm{m}^{-3}\right), C_{\mathrm{d}}$ is $C$ at the deflection point and $I_{\max }$ is the asymptotic maximum $I$, calculated as the average $I$ value for $C \geq C_{\mathrm{d}}$.

For Type II we used the Ivlev (1961) equation:

$$
I=I_{\max }\left[1-\exp \left(-a C / I_{\max }\right)\right]
$$

The logistic equation for the Type III model was:

$$
I=I_{\max } /\left(1+\exp \left[\left(K_{\mathrm{c}}-C\right) / a\right)\right]
$$

where $K_{\mathrm{c}}$ is a constant defined as the food concentration for $I=I_{\max } / 2$.

To compare between models, minimisation of the mean-square error (MSE) was used as the criterion for goodness of fit. The significance of differences in variances between regressions was tested using a 2-tailed F-test on the MSE (Rothhaupt 1990).

\section{RESULTS}

The hydrographic features of the study area are those of a typical temperate sea, the main characteristic being the transition from the winter-spring mixing to the summer-autumn stratification with the development of a thermocline at about $40 \mathrm{~m}$ (Fig. 2). A more detailed description of physical and chemical characteristics was presented by Llope et al. (2006). An unusual feature was observed during February at Stn E3: the appearance of a low salinity water mass in the upper $50 \mathrm{~m}$ of the water column (data not shown). Chl a concentration profiles were characterised by a winter-spring maximum (Fig. 3). During February, a phytoplankton bloom developed in the low salinity water mentioned above, reaching the highest chl a concentration for the whole sampling period.

Data on phytoplankton abundance were only available from Stn E2. The highest numbers were observed during the spring bloom (Fig. 4), when diatoms were the dominant group in the community. A second maximum was reached in late summer (August and September), when the most abundant phytoplankton were both diatoms and Crysophyceae. This pattern did not coincide with that of chl a concentration. The summer increase in phytoplankton abundance started in August, but the chl a concentration did not peak until September.

\section{Metazooplankton and phytoplankton abundance}

Copepods were the most abundant metazooplankton group in both $>200$ and $<200 \mu \mathrm{m}$ size fractions (Tables 1 \& 2). They represented on average $72.5 \%$ of total abundance in the $>200 \mu \mathrm{m}$ fraction and $93 \%$ in both fractions. On average, $81 \%$ of total copepods belonged 

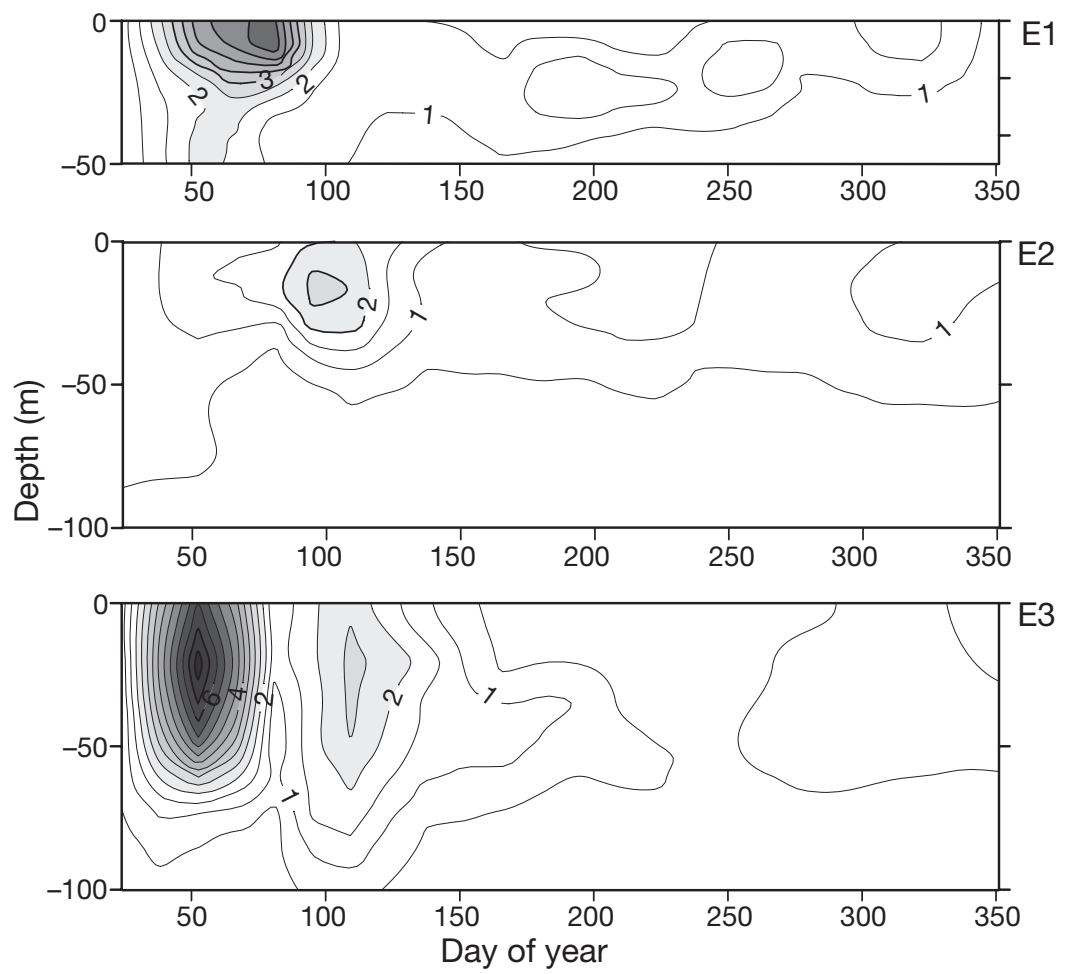

Fig. 3. Vertical profiles of chl a concentration $\left(\mu \mathrm{g} \mathrm{l}^{-1}\right)$ at Stns E1, E2 and E3 in January to December 2003

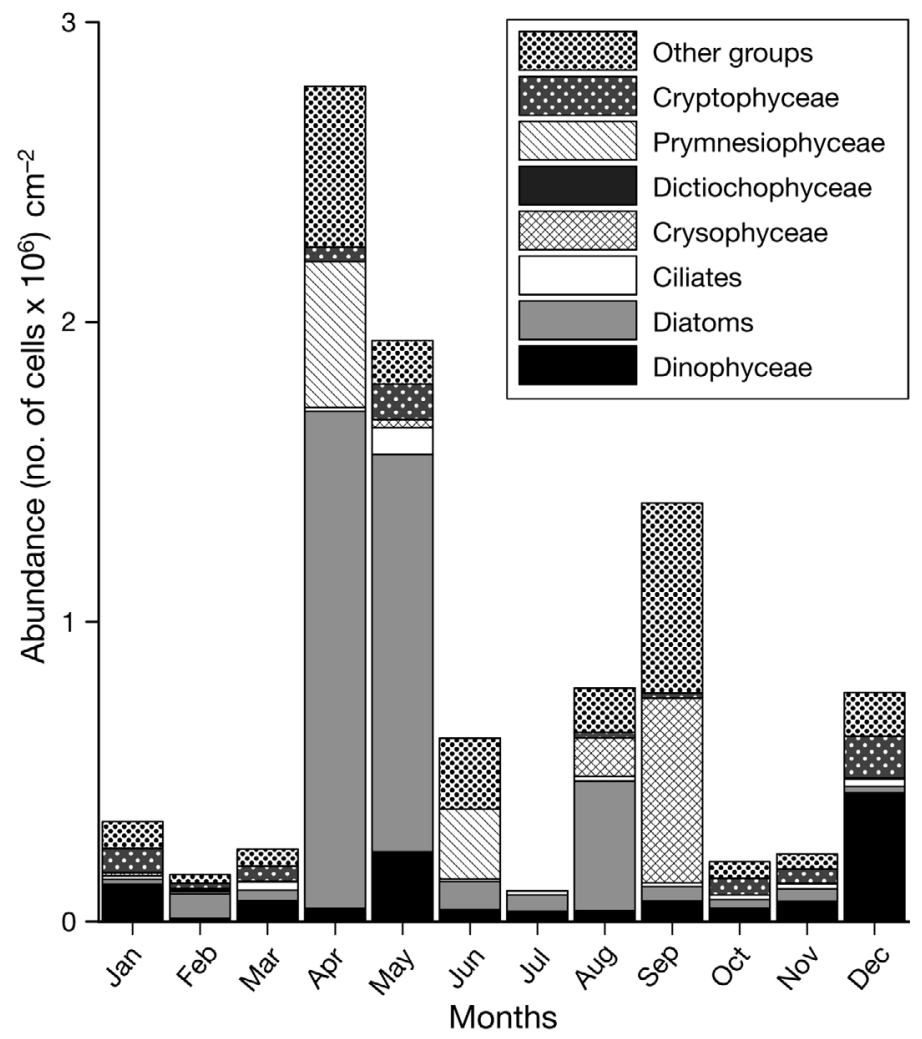

Fig. 4. Seasonal variation in phytoplankton abundance at Stn E2. Other groups: cells belonging to minority groups and those that could not be identified using an inverted microscope given their small size to the $<200 \mu \mathrm{m}$ size fraction. Only cirriped larvae outnumbered them in the $>200 \mu \mathrm{m}$ fraction in April and February at Stns E1 and E2, respectively. Appendicularians were also found in high numbers throughout most of the year, and doliolids were abundant during late summer and autumn, reaching their highest density in October at E3.

Given that copepods represented the major group of mesozooplankton, changes in the relative biomass of each size fraction (Fig. 5) can be related to changes in copepod community size structure. However, it is necessary to take into account the cases in which cirriped larvae were abundant (February at all 3 stations and April at Stn E1). Cirriped larvae are mostly represented in the 200 to $500 \mu \mathrm{m}$ size fraction. There was a significant increase in the biomass of this fraction in February at Stn E2 coinciding with the highest numbers of cirriped larvae. Also, appendicularians could account for a significant proportion of total biomass, particularly in spring and early summer.

Changes in mesozooplankton biomass were not directly related to observed changes in the number of copepods. The highest mesozooplankton biomass was found in spring, coincident with a rise in the abundance of large copepods, but occurring at lower densities than during periods in which small species were dominant. The different sampling techniques used for both parameters could, in part, account for these observed differences. Net hauls were deployed to $50 \mathrm{~m}$ at all 3 stations for taxonomic analysis and gut contents, but were deployed to 50, 100 and $200 \mathrm{~m}$ at Stns E1, E2 and E3, respectively, for mesozooplankton biomass. Thus, the different depths sampled at Stns E2 and E3 would render the results incomparable given that copepods are distributed heterogeneously in the water column. This may be the reason why the highest number of copepods that were observed in February at Stn E3 did not match with the biomass estimates.

Seasonal changes in the number of copepods (Fig. 6) were mainly due to changes in nauplii numbers. However, the patterns were different at each of the 3 stations. A significant increase in abundance was ob- 


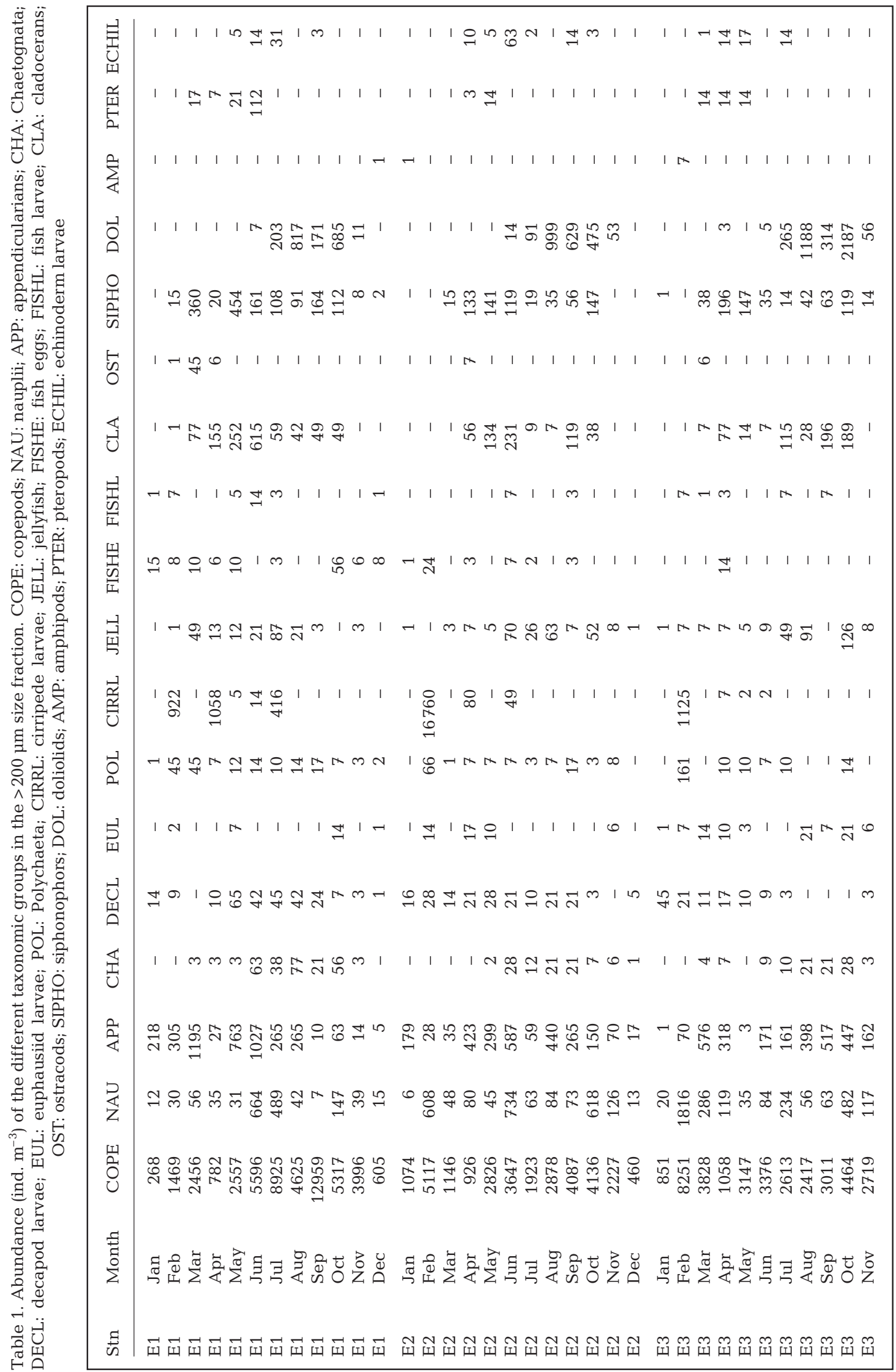


Table 2. Abundance (ind. $\mathrm{m}^{-3}$ ) of the different taxonomic groups in the $<200 \mu \mathrm{m}$ size fraction. NAU: nauplii; COPE: copepods; APP: appendicularians; CIRRL: cirripede larvae

\begin{tabular}{|llrrrr|}
\hline Stn & Month & NAU & COPE & APP & CIRRL \\
\hline E1 & Jan & 2173 & 391 & 295 & - \\
E1 & Feb & 2480 & 548 & 108 & - \\
E1 & Mar & 2241 & 1509 & 267 & - \\
E1 & Apr & 1062 & 258 & 42 & 189 \\
E1 & May & 4317 & 887 & 112 & - \\
E1 & Jun & 16306 & 1146 & 279 & 14 \\
E1 & Jul & 12181 & 1271 & 28 & - \\
E1 & Aug & 26715 & 5882 & 140 & - \\
E1 & Sep & 18835 & 145003 & 35 & - \\
E1 & Oct & 30271 & 6239 & 70 & - \\
E1 & Nov & 12631 & 3745 & 49 & - \\
E1 & Dec & 4692 & 685 & 8 & - \\
E2 & Jan & 5669 & 1235 & 129 & - \\
E2 & Feb & 5498 & 1184 & - & 148 \\
E2 & Mar & 7769 & 1921 & 101 & 7 \\
E2 & Apr & 1740 & 545 & 182 & 14 \\
E2 & May & 6658 & 814 & 7 & 3 \\
E2 & Jun & 8460 & 2194 & 91 & - \\
E2 & Jul & 10263 & 1446 & - & - \\
E2 & Aug & 17445 & 4555 & 363 & - \\
E2 & Sep & 45780 & 9334 & 154 & - \\
E2 & Nov & 15244 & 4653 & - & - \\
E3 & Jan & 4200 & 813 & 4 & - \\
E3 & Feb & 7140 & 1097 & 35 & - \\
E3 & Mar & 14594 & 4443 & 803 & - \\
E3 & Apr & 2522 & 660 & 227 & - \\
E3 & May & 12886 & 1740 & 3 & - \\
E3 & Jun & 13106 & 2746 & 84 & - \\
E3 & Jul & 9746 & 831 & 35 & - \\
E3 & Aug & 10249 & 5379 & 91 & - \\
E3 & Sep & 21084 & 3577 & 252 & - \\
E3 & Oct & 48666 & 8188 & 182 & - \\
E3 & Nov & 17535 & 3486 & 126 & - \\
E3 & Dec & 3138 & 1095 & 70 & - \\
\hline
\end{tabular}

served in June at Stn E1. This increase did not occur until August at Stn E2 and September at Stn E3. Following this peak, numbers remained high until November at all 3 stations.

To identify the variables driving copepod population dynamics, we used linear regressions to relate the abundance of nauplii to temperature and chl a concentration in the water. The increase in nauplii abundance during favourable conditions should also be dependent on the number of adult copepods. Therefore, the regression analyses were also applied using the relationship 'number of nauplii/number of copepods' (nau/cop) for each period. We found a significant positive relationship between temperature and total nauplii $\left(\mathrm{r}^{2}=0.277, \mathrm{p}=0.001\right)$, as well as nau/cop $\left(\mathrm{r}^{2}=0.126, \mathrm{p}=0.039\right)$. Chl a concentration only showed a significant positive relationship with
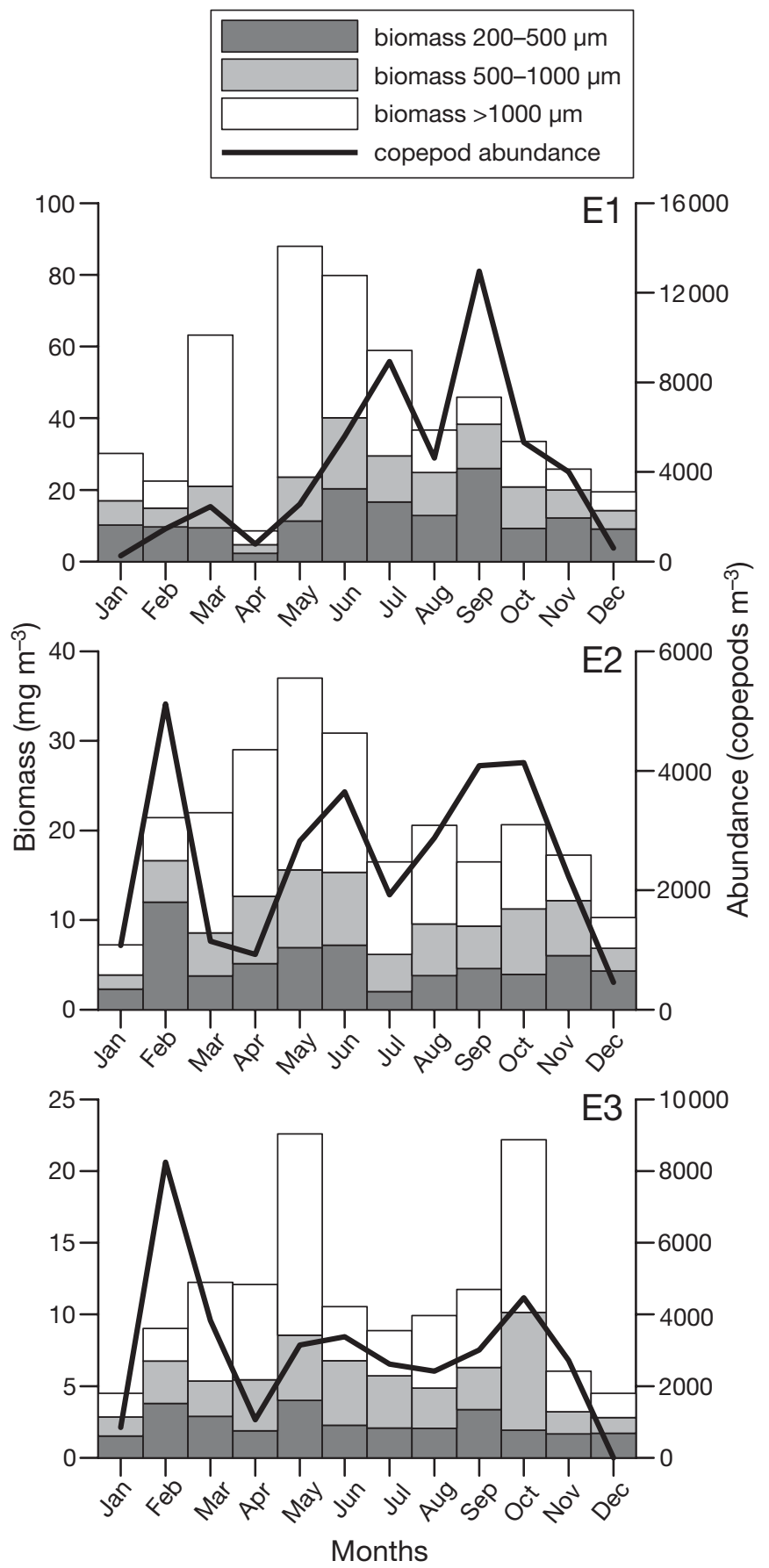

Fig. 5. Seasonal variation in mesozooplankton biomass and copepod abundance at the 3 sampling stations (Stns E1, E2 and E3). Note different scales

total nauplii $\left(\mathrm{r}^{2}=0.224, \mathrm{p}=0.005\right)$, with nauplii numbers decreasing at higher chl a concentrations.

Copepod abundance followed a different pattern than chl a concentration at the 3 stations. However, at Stn E2 an increase in phytoplankton numbers coincided with an increase in copepod abundance. 


\section{Ingestion rates and functional responses}

Gut contents of nauplii and cop $<200 \mu \mathrm{m}$ ranged from 0.004 to 0.082 and 0.003 to $0.315 \mathrm{ng}$ chl a equiv. ind. ${ }^{-1}$, respectively. Carbon ingestion rates of nauplii and cop $<200 \mu \mathrm{m}$ (Figs. $7 \& 8$, respectively) correspond to the grazing of 0.3 to $9.6 \%$ of phytoplankton stock daily, and 0.49 to $19.9 \%$ of primary production at Stn E2 (Fig. 9).


Fig. 6. Seasonal variation in nauplii, copepodites and copepods (cop) $<200 \mu \mathrm{m}$ and cop $>200 \mu \mathrm{m}$ abundance and integrated chl a concentration in the water column at Stns E1, E2 and E3. Note different scales
The 3 models of functional responses were fitted to ingestion data (Fig. 10), and their parameters were determined using the least-squares criterion (Table 3). Although the Type III model showed a lower MSE, there were no notable differences in the explained variance between models ( $p>0.3$ in all cases).

Both nauplii and cop $<200 \mu \mathrm{m}$ showed a saturation

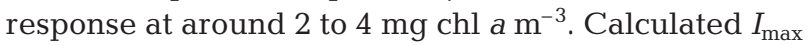
may have been significantly underestimated due to the scarcity of data at high chl a concentrations. This is more evident for cop $<200 \mu \mathrm{m}$, where an $I_{\max }$ of at least $2 \mu \mathrm{g} \mathrm{C} \mu \mathrm{g}^{-1}$ copepod $\mathrm{C} \mathrm{d}^{-1}$ would be expected (Fig. 10). In the case of the Type I model, the equation for a nonsaturating response was also plotted for cop $<200 \mu \mathrm{m}$ by not including data obtained during the highest chl $a$ concentration, as those data were biasing fits towards



Fig. 7. Nauplii ingestion rates and average chl a concentration in the water column during the annual cycle at Stns E1, E2 and $\mathrm{E} 3$. Bars: average values $\pm \mathrm{SD}$ 
a lower $I_{\max }$ value. The origin of such low ingestion rates at high chl a concentrations cannot be explained with the available information; however, we hypothesise that copepods may exhibit reduced herbivory when diatoms dominate the phytoplankton assemblage.

\section{DISCUSSION}

\section{Copepod abundance and seasonal changes in the community}

Nauplii dominated the copepod community in terms of abundance ( $67 \%$ of total copepods). Densities throughout the annual cycle were 12 nauplii $l^{-1}$ on



Fig. 8. Copepodites and copepods (cop) $<200 \mu \mathrm{m}$ ingestion rates and average chl a concentration in the water column during the annual cycle at Stns E1, E2 and E3. Bars: average values $\pm \mathrm{SD}$ average and were within the same range as others found in coastal zones (Roff et al. 1995, Calbet et al. 2001, Pedersen et al. 2005). In some cases, nauplii abundances were more than 1 order of magnitude lower than in more productive systems, such as the northern Adriatic Sea (Lucic et al. 2003) or the inland Sea of Japan (Uye et al. 1996). However, it is possible


Fig. 9. Nauplii and copepodites and copepods (cop) $<200 \mu \mathrm{m}$ grazing impact on phytoplankton biomass (at Stns E1, E2 and E3) and primary production (pp) (at Stn E2) during the annual cycle 


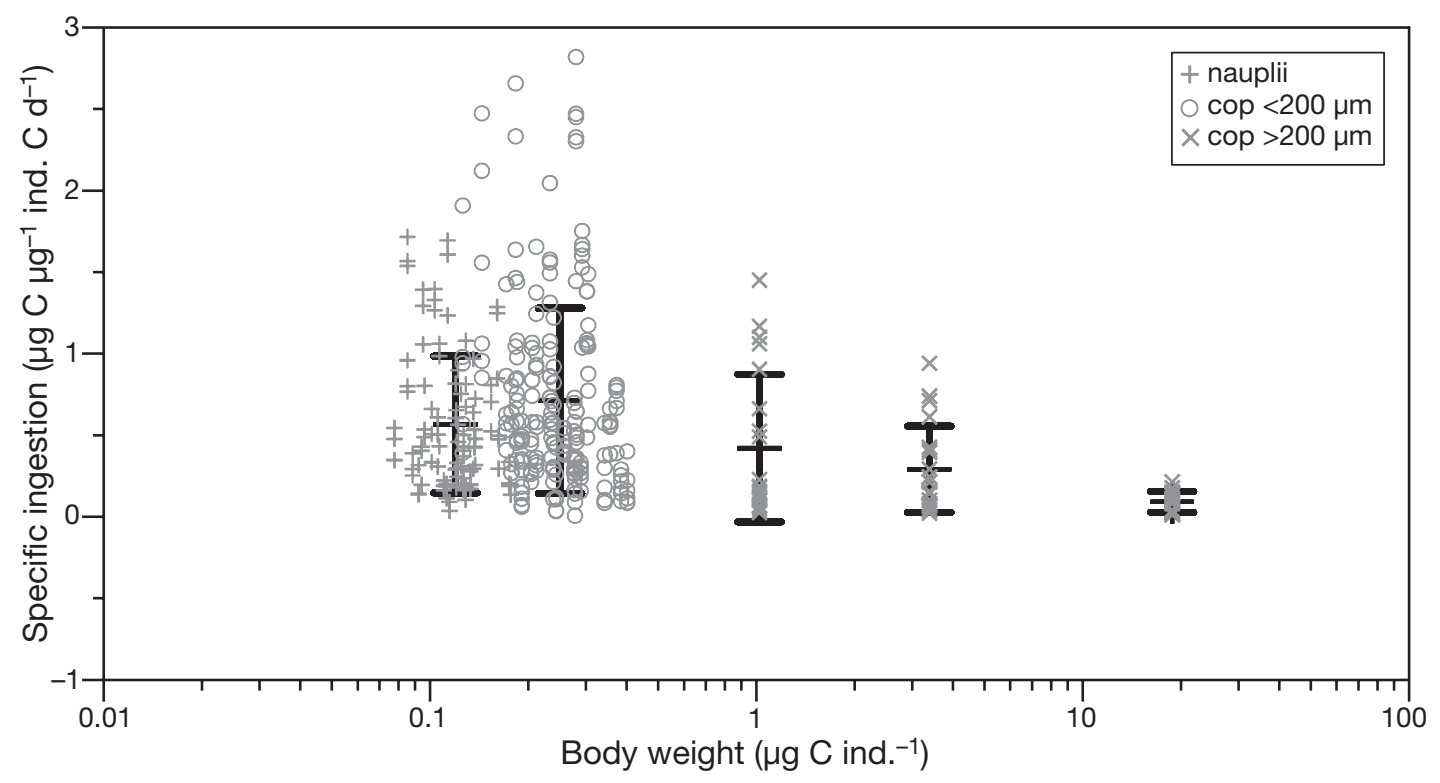

Fig. 10. Specific ingestion rates for all stages and size fractions of copepodites and copepods (cop) in the study area during the annual cycle. Data from Huskin et al. (2006) and the present study. Average values and sample standard deviations are plotted for each size fraction

that nauplii were undersampled in this study, although a $53 \mu \mathrm{m}$ mesh net was used. Lucic et al. (2003) found that nauplii with $<80 \mu \mathrm{m}$ body length could account for $30 \%$ of total nauplii in the Adriatic Sea. In our samples, such small nauplii were scarce, even though small copepod species such as Oithona nana and Oncaea media are abundant in the study area. Thus, we suspect that nauplii from these species were not efficiently sampled by the net. What is the role of such small organisms in coastal food webs? Lucic et al. (2003), working on the principle that they had found a significant correlation between small nauplii and bacteria, suggested that small nauplii had a mainly bacterivorous diet. They did not find this correlation with larger nauplii, suggesting this diet was unique to small nauplii. Although bacterivory had been previously described by Turner \& Tester (1992) and Roff et al. (1995), it is still not clear under what circumstances it occurs, as other studies have found that particles $<2 \mu \mathrm{m}$ escaped predation by other species of copepod nauplii (e.g. Sommer et al. 2000). If we assume that small nauplii indeed exploit bacteria, their undersampling in this study would not affect the estimated impact on the phytoplankton community. Even if they feed on phytoplankton, total community ingestion would not be expected to be significantly higher, due to their small size and, consequently, low gut contents.

It would be logical to expect the number of copepods to be influenced by the availability of food supply. In spite of this, we found that nauplii abundance was negatively correlated with chl a concentration in the water. One possible explanation for this would be that heterotrophic prey were more abundant when chlorophyll-bearing prey decrease. Even though the abundance of other potential prey, apart from phytoplankton, was not measured, this is considered to be an unlikely option. Other authors have suggested predation (Calbet et al. 2001, Lawrence et al. 2004) and improved competitive advantage of protozoans versus

Table 3. Mean-square error (MSE) and parameters for each of the 3 types of functional responses for nauplii and cop

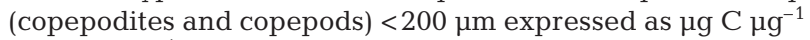
nauplii $\mathrm{C} \mathrm{d}^{-1}$ and phytoplankton concentration at the deflec-


Ns: minimum estimate for the maximum specific ingestion rate $\left(I_{\max }\right)$ with a non-saturation Type I model; $\mathrm{S}: I_{\max }$ value obtained with a saturation Type I model. (MSE obtained for the saturation model)

\begin{tabular}{|llll|}
\hline Model & & Nauplii & Cop $<200 \mu \mathrm{m}$ \\
\hline Type I & $a$ & 0.49 & 0.645 \\
& $C_{\mathrm{d}}$ & 3.17 & 1.83 \\
& $I_{\max }$ & 1.56 & Ns $=2.3 \quad \mathrm{~S}=1.55$ \\
& MSE & 0.102 & $0.265(\mathrm{~b})$ \\
Type II & $a$ & 0.65 & 0.94 \\
& $I_{\max }$ & 1.72 & 1.58 \\
& MSE & 0.102 & 0.262 \\
Type III & $a$ & 0.96 & 0.78 \\
& $K_{\mathrm{c}}$ & 1.72 & 1.29 \\
& $I_{\max }$ & 1.60 & 1.63 \\
& MSE & 0.097 & 0.243 \\
\hline
\end{tabular}


metazoans at higher food concentrations (Uye et al. 1996) as causes for the lack of relationship between copepod and nauplii abundances and chl a concentration in the water. Saiz et al. (1999) found an increase in copepod egg production across the natural nutrient gradient from 'oligotrophic' oceanic waters to 'eutrophic' shelf waters, which did not reflect an increase in the abundance of copepods, and suggested that predation or advection may uncouple production from abundance. Bottom-up and top-down controls on reproductive efficiency could be considered within a more general theory as that proposed by Micheli (1999). This author suggested that these controls attenuate through marine food webs, and in general, there may be a weak coupling between phytoplankton and herbivores.

However, having observed phytoplankton and zooplankton annual cycles, the explanation that seems more reasonable is that a combination of 3 factors drives copepod population dynamics in this area: (1) water temperature, (2) quantity and (3) quality of available food. Some observations (e.g. Mauchline 1998) have shown that environmental temperature rather than phytoplankton abundance controls egg production in copepods. In this way, daily rates of egg production increase with temperature to a maximum but then decrease with further increases in temperature. In this study, a positive influence of temperature on nauplii abundance was found, and this latter variable was used as a proxy of reproductive success. Other studies have pointed out that the quality as well as the quantity of available food is important; high quality encourages production of successive egg masses and clutches (see references in Mauchline 1998).

Ianora et al. (2004) found that dominant diatom species reduce the reproductive success of grazers. The aldehydes that prevent copepod larval development were identified, introducing a new angle to the debate about the positive or negative effect of diatoms in copepod populations. Although not all bloom-forming species produce aldehydes, these findings provide a plausible mechanism for the apparent poor timing between spring bloom development and the arrival of the bulk of the copepod stock. Diatoms are the major component of the phytoplankton spring bloom in the Cantabrian Sea. Thus, the fact that there was no significant relationship between nauplii abundance and $\mathrm{chl}$ a concentration in the water (an indicator of 'quantity' of available food), suggests the interference of the 'quality' factor.

These 3 factors in combination influence the most suitable period, between spring and the end of summer, for copepod breeding. Although chl a concentration is highest in spring, water temperature and food quality are low (phytoplankton assemblages are main- ly composed of diatoms), whereas in the summer, the water temperature is higher and there is a second lesspronounced peak in chl a as a result of the growth of higher quality phytoplankton species. In August, as the abundance of copepods started to increase, the number of diatoms increased; their populations were probably enhanced by short-lived upwellings that are a common event in the area during summer (Llope et al. 2006). However, the relative abundance of diatoms was lower than in the spring, and it has been pointed out that a mixed diet serves to dilute the toxin, lowering the adverse effects on copepod recruitment (Ianora et al. 2004). The timescale has been suggested as another important factor in considering the negative effects of diatoms (Irigoien et al. 2002). The shorter period in which they were dominant during summer could not have been enough to cause the same deleterious effects as during spring bloom.

As phytoplankton taxonomy was not available for Stns E1 and E3, only chl a concentration could be used to compare copepod and phytoplankton annual cycles. Although chl $a$ is sometimes an imperfect index of the availability of phytoplankton, as observed for Stn E2, it provides some information, and we can expect that succession followed a similar pattern to that at Stn E2. The seasonal distribution of copepods at Stns E1 and E3 supports the theory explained above. At Stn E1, where chl a concentration remains high throughout the year, seasonal changes in breeding would be mainly controlled by temperature and food quality for the majority of copepod species, while at Stn E3, lower phytoplankton concentrations at the beginning of summer would delay reproduction until the end of summer, when chl $a$ increases and water temperature is still high.

A water mass with special characteristics was observed at Stn E3 in February. In the upper 50 m, water had lower salinity and much higher chl a concentration than in Stn E2. The occurrence of slope fronts has previously been described in this area (González et al. 2003). The presence of this kind of structure in outer waters could act as a barrier for the surface transport of fresh water from the Nalón River, explaining the accumulation of this 'low-salinity water' just before the front. The meteorological conditions in the area were characterised by weak winds several days prior to the sampling (M. Llope pers. comm.), which would have favoured the formation and maintenance of this structure. Differences between copepod abundance and biomass that were found during this month were possibly due to the fact that the majority of copepods accumulated in the upper $50 \mathrm{~m}$, where the bloom developed. Nutrient analysis (data not shown) indicated that the bloom was at an advanced stage in development. 


\section{Ingestion rates}

Ingestion rates obtained in this study should be considered with caution, as the methodology used has some potential sources of error, such as the calculation of gut evacuation rates and the possibility of differences in diel feeding periodicities in copepods. Ingestion rates estimated with this method must be considered minimum rates due to the uncertainty of pigment degradation in copepod guts. Some authors have applied an average value of $33 \%$ of degradation to colourless products to correct their estimates (Dam \& Peterson 1988). However, it is still not clear under what circumstances, and to what extent, this correction reduces the error in ingestion estimates (discussed by López et al. 2007).

When nauplii were selected for gut fluorescence analysis, developmental stages were not considered. There is still a debate as to which naupliar stage is the first to feed. Most calanoid copepods are considered to start feeding during nauplii stage III (NIII), but there are differences between species (Mauchline 1998). Cyclopoid and poecilostomatoid nauplii, on the other hand, can start feeding immediately after hatching (Uchima \& Hirano 1986, Paffenhöfer 1993). Sorting nauplii into feeding stages would have been rather difficult and time consuming. Thus, all types of nauplii were selected and counted to ensure that real community ingestion rates on phytoplankton were obtained, recognising that individual rates of feeding stages would be underestimated. The high proportion of nauplii in copepod populations indicated high mortality rates during development. This suggests that the first naupliar stages (which do not feed) should be much more abundant than the last, indicating a significant underestimation of individual ingestion rates of feeding stages.

Specific ingestion rates ranged from 0.03 to $1.71 \mu \mathrm{g} \mathrm{C}$ $\mu \mathrm{g}^{-1}$ nauplii $\mathrm{C} \mathrm{d}^{-1}$ and 0.03 to $2.82 \mu \mathrm{g} \mathrm{C} \mathrm{\mu g}^{-1}$ copepod $\mathrm{C}$ $\mathrm{d}^{-1}$. As no field studies have analysed nauplii grazing rates in temperate seas, we could only compare our results to the scarce information from studies undertaken at high latitudes, mainly focusing on the largest nauplii fraction (Table 4). Data presented here are in the same range as values obtained in those studies, although they are usually higher than previous values for nauplii feeding at similar phytoplankton concentrations. Ingestion rates found for cop $<200 \mu \mathrm{m}$ were also sometimes higher than those reported in the literature. Mauchline (1998) carried out a review of copepod ingestion rates on phytoplankton and reported mean values ranging between 0.02 and $1.83 \mu \mathrm{g}$ $\mathrm{C} \mathrm{\mu g}^{-1}$ copepod $\mathrm{C} \mathrm{d}^{-1}$ for copepodites and between 0.013 and $1.5 \mu \mathrm{g} \mathrm{C} \mathrm{\mu g}^{-1}$ copepod $\mathrm{C} \mathrm{d}^{-1}$ for adult copepods.

Pigment degradation in copepod guts was not assessed during this study, but, as previously pointed out, our estimates of nauplii and copepod ingestion rates are relatively high. This supports the idea that high chl a degradation rates in copepod guts are not the rule, unless values obtained using alternative experiments were also significant underestimations of real rates.

The study by Huskin et al. (2006) carried out during 1998 using the same methodology and in the same area for copepodites and copepods $>200 \mu \mathrm{m}$ (cop > $200 \mu \mathrm{m})$ provides an opportunity to compare ingestion rates for different sizes and developmental stages of copepods. Huskin et al. (2006) found that cop > $200 \mu \mathrm{m}$ at Stns E1 and E2 ingested on average $7 \%$ of the chlorophyll standing stock daily, ranging between 0.36 and $25.5 \%$, and between 1 and $53 \%$ of primary production at Stn E2. The ingestion rates reported here for the $<200 \mu \mathrm{m}$ size fraction averaged $2.8 \%$ of the chlorophyll standing stock and $5.7 \%$ of daily primary production. Thus, the total copepod ingestion on phytoplankton never reaches $100 \%$ of primary production, although during a few months of the year it surpasses $50 \%$ and plays a significant role in the control of phytoplankton populations. Not including the $<200 \mu \mathrm{m}$ fraction when measuring the impact of copepod community feeding results in an underestimation of about $30 \%$. A similar proportion of $\mathrm{C}$ ingested by the different stages of copepods was obtained by Sommer et al. (2000), who found that copepod total ingestion on seston particles was 4 times higher than for nauplii stages.

We transformed the ingestion rates reported by Huskin et al. (2006) to specific ingestion rates to enable comparisons between the different sizes and stages of copepods. As copepod length and/or weight had not been measured in the previous study, a sample was taken at Stn E2 with a WP-2 net (200 $\mu \mathrm{m}$ mesh) and fractionated in the same way that Huskin et al. (2006)
Table 4. Specific ingestion rates of copepod nauplii feeding on natural phytoplankton reported by other authors

\begin{tabular}{lccl} 
Copepod species & $\begin{array}{c}\text { Phytoplankton } \\
\text { concentration } \\
\left(\mu \mathrm{C} \mathrm{C} \mathrm{l}^{-1}\right)\end{array}$ & $\begin{array}{c}\text { Specific ingestion } \\
\text { rate }\left(\mu \mathrm{g} \mathrm{C} \mathrm{gg}^{-1}\right. \\
\left.\text { nauplii } \mathrm{C} \mathrm{d}^{-1}\right)\end{array}$ & Source \\
\hline $\begin{array}{l}\text { Calanus } \\
\text { finmarchicus }\end{array}$ & $27.6-212$ & $0.11-0.46$ & Irigoien et al. (2003) \\
$\begin{array}{l}\text { Calanus spp. } \\
\text { Acartia spp. }\end{array}$ & $5-20$ & $0.0087-0.012$ & Turner et al. (2001) \\
$\begin{array}{l}\text { Acartia spp. } \\
\text { Copepod nauplii } \\
\text { assemblage }\end{array}$ & $180-420$ & $0.28-0.52$ & Tackx et al. (1990) \\
& $15-68$ & $0.79-2.8$ & White \& Roman (1992) \\
& & $0.08-0.29$ & Uitto (1996) \\
\hline
\end{tabular}


did (200 to $500 \mu \mathrm{m}, 500$ to $1000 \mu \mathrm{m}$ and $>1000 \mu \mathrm{m})$. In the laboratory, a sample of 60 copepods from each fraction was measured under a stereomicroscope, and C weight was calculated using the same equation as for cop $<200 \mu \mathrm{m}$. Data from both studies were plotted in Fig. 10 with cop $>200 \mu \mathrm{m}$ being only an approximation, given that the same length value was used for all samples. Previous studies have suggested nauplii may have weight-specific ingestion rates 3 to 4 times higher than adults (Paffenhöfer 1971, Lonsdale et al. 1996). In contrast, we calculated average specific ingestion rates of 0.56 for nauplii, 0.71 for cop $<200 \mu \mathrm{m}, 0.42$ for cop 200 to $500 \mu \mathrm{m}, 0.29$ for cop 500 to $1000 \mu \mathrm{m}$ and 0.09 for cop $>1000 \mu \mathrm{m}$. Although there is a trend of decreasing specific ingestion rate with increasing body weight, copepod and nauplii specific rates are more similar than previously reported. However, this may be because previous studies had not included non-feeding naupliar stages in their analysis.

We found that appendicularians are also an important zooplanktonic component in the area. Their grazing rates have been estimated in a previous seasonal study (López-Urrutia et al. 2003), which found that on average they consumed $8 \%$ of daily primary production, reaching values as high as $60 \%$. This suggests that in some cases, this group could be ingesting a higher amount of phytoplankton stock than copepods.

\section{Functional responses}

Functional response equations provide a useful tool to predict the trophic impact caused by copepods when it is not possible to carry out specific experiments. Two conceptual models (Lam \& Frost 1976, Lehman 1976) pointed out that a Type III functional response (Holling 1965) is one that maximises the net gain of energy for a copepod. They predict that below a critical food concentration, the energy expenditure of the feeding process is higher than the gain from the assimilation of the food collected. Thus, an animal in this situation may reduce, or even cease, its feeding activity to minimise energy loss. We found that a Type III model best fitted our data. However, models did not differ significantly (Table 3). Furthermore, the Type III plot had a positive ' $y$ intercept' (Fig. 11). Thus, it would predict an unreal situation, viz. individuals with chl $a$ in their guts when there is no phytoplankton in the environment. Although López et al. (2007) observed a better fit to a Type III model with nauplii feeding on phytoplankton cultures, we think in this case, a Type II response would be theoretically more suitable. The difference between Type II and Type III models is that Type III predicts a reduction in grazing rates at low food concentrations. We obtained functional responses by studying only ingestion on autotrophic prey, but most copepods are omnivores (Turner 2004), and during each sampling period, heterotrophic prey could make up the rest of the copepod diet. The presence of this alternative food supply, when phytoplankton abundance is low, could justify a Type II functional response, as copepods could continue filtering at the same rate, taking advantage of all kinds of prey and not compromising their energy balance. Experiments involving different prey would be necessary to elucidate this aspect.

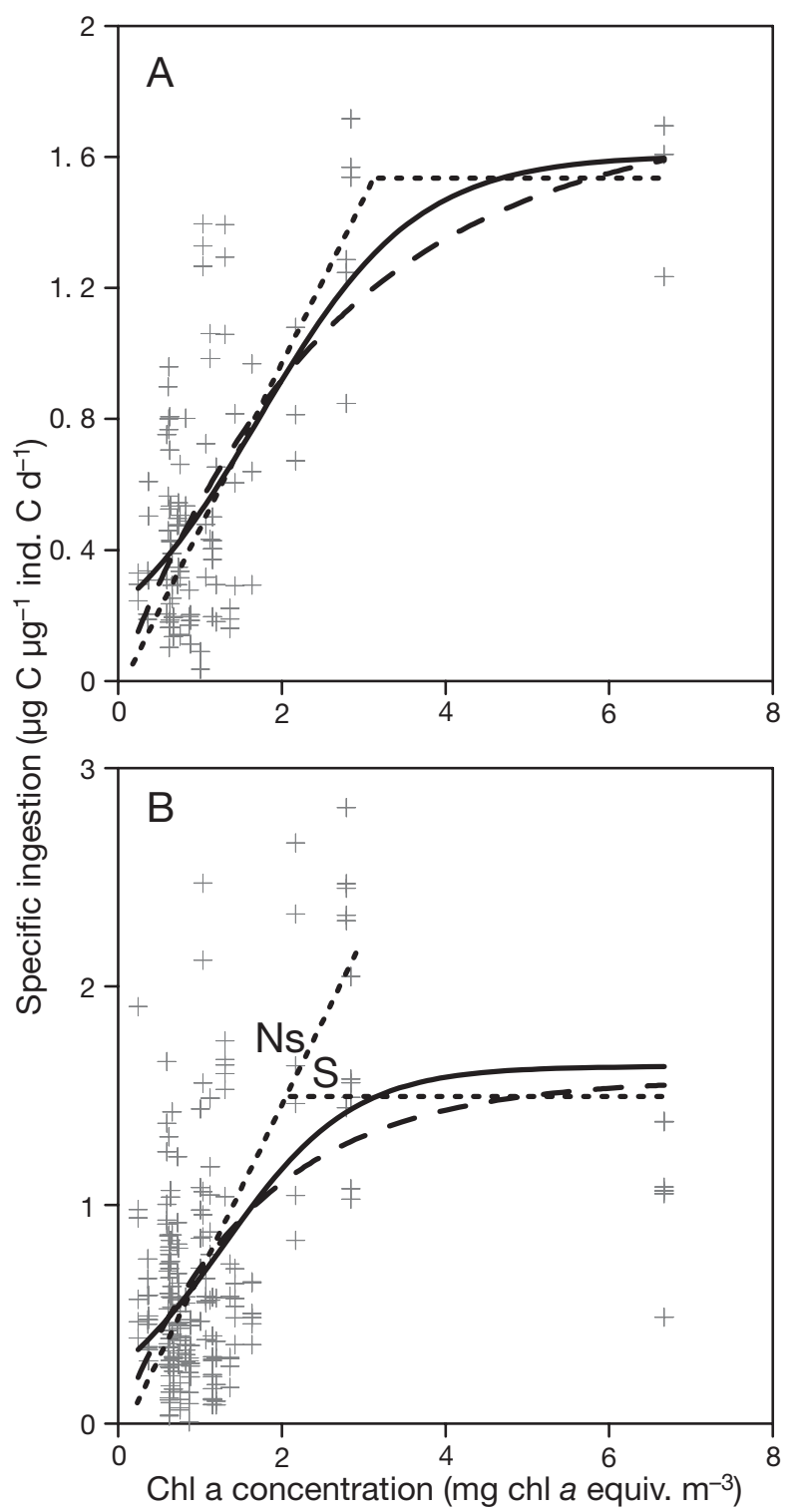

Fig. 11. (A) Nauplii and (B) copepodites and copepods (cop) $<200 \mu \mathrm{m}$ specific ingestion rates as a function of chl a concentration in the water. Equations for functional responses are fitted to data. Type I is denoted by short dashed lines (for cop $<200 \mu \mathrm{m}$, Ns: non-saturation model, S: saturation model);

Type II by long dashed lines; and Type III by solid lines 
Both adults and juveniles showed saturation responses at around $240 \mathrm{\mu g} \mathrm{C} \mathrm{l}^{-1}$, although the scarcity of samples at high chl a concentrations could have biased the calculation. In the case of cop $<200 \mu \mathrm{m}$, if we do not take into account data obtained for the highest chl a concentration, the Type I model would predict an $I_{\max }$ higher than 2, i.e. the model would not reach saturation in the range of available concentrations. In our study area, saturation concentrations were only found at the beginning of the spring phytoplankton bloom. Frost (1972) found a similar saturation concentration for adult Calanus pacificus females. In contrast, experiments with nauplii feeding on the small phytoplankton species Isochrysis galbana (López et al. 2007) showed 2 to 3 times higher saturation concentrations. These authors suggested that nauplii in natural conditions, where prey with more suitable sizes are available, are likely to show saturation responses at lower chl a concentrations than in the laboratory.

A study, such as this one, that includes all size fractions of copepods is necessary in order to gain a better understanding of plankton population dynamics in the Cantabrian Sea. However, to model copepod-mediated carbon fluxes in the ocean, copepods stages should not be considered as a single group but as different compartments. Due to the small size of their pellets, nauplii are not likely to be as important in the biological pump as adult copepods. However, they may play an important role in surface recycling processes (Green et al. 1992). Nauplii have also been suggested to be critical intermediaries between 'classical' and microbial food webs, given that they can feed on the pico- and nanoplankton (Turner \& Tester 1992, Roff et al. 1995) that larger copepods may be unable to consume directly.

Although the sparse information available on copepod nauplii makes it difficult to determine their quantitative and ecological importance, this study has provided a first approach in assessing their impact on phytoplankton populations in temperate seas, which will enable us to reach an unbiased global view of the role of metazooplankton as consumers of phytoplankton.

Acknowledgements. This work was possible thanks to an agreement between Universidad de Oviedo and Instituto Español de Oceanografia in the context of the project 'RADIALES', and was funded by the following projects: CICYT, MAR1999-1072-C03-03; FICYT, 'Apoyo a Grupos de Excelencia'; MEC, REN2003-09549-C03-01; and an FPU grant by MEC to E.L. We thank the crew of the RV 'Jose Rioja' for their help with sample collection. Thanks are also due to the Group of Biological Oceanography of Universidad de Oviedo for their help with the sampling, and I. Huskin and D. Fernández for their technical advice during the first stages of this study. We are also grateful to J. L. Acuña and one anonymous referee for their useful comments on an earlier version of the manuscript. E. San Martin kindly improved the English.

\section{LITERATURE CITED}

Calbet A, Garrido S, Saiz E, Alcaraz M, Duarte CM (2001) Annual zooplankton succession in coastal NW Mediterranean waters: the importance of the smaller size fractions. J Plankton Res 23:319-331

Dam HG, Peterson WT (1988) The effect of temperature on the gut clearance rate constant of planktonic copepods. J Exp Mar Biol Ecol 123:1-14

Frost BW (1972) Effects of size and concentration of food particles on the feeding behavior of the marine planktonic copepod Calanus pacificus. Limnol Oceanogr 17:805-815

González N, Anadón R, Viesca L (2003) Carbon flux through the microbial community in a temperate sea during summer: role of bacterial metabolism. Aquat Microb Ecol 33: $117-126$

González-Quirós R, Anadón R (2001) Diet breadth variability in larval blue whiting as a response to plankton size structure. J Fish Biol 59:1111-1125

Green EP, Harris RP, Duncan A (1992) The production and ingestion of faecal pellets by nauplii of marine calanoid copepods. J Plankton Res 14:1631-1643

Holling CS (1965) The functional response of predators to prey density and its role in mimicry and population regulation. Mem Entomol Soc Can 45:3-60

Huskin I, López E, Viesca L, Anadón R (2006) Seasonal variation of mesozooplankton distribution and copepod grazing in the Central Cantabrian Sea (Southern Bay of Biscay). Sci Mar 70S1:119-130

Ianora A, Miralto A, Poulet SA, Carotenuto Y and others (2004) Aldehyde suppression of copepod recruitment in blooms of a ubiquitous planktonic diatom. Nature 429:403-407

Irigoien X, Harris RP, Verheye HM, Joly P and others (2002) Copepod hatching success in marine ecosystems with high diatom concentrations. Nature 419:387-389

Irigoien X, Titelman J, Harris RP, Harbour D, Castellani C (2003) Feeding behaviour of Calanus finmarchicus nauplii in the Irminger Sea. Mar Ecol Prog Ser 262:193-200

Ivlev VS (1961) Experimental ecology of the feeding of fishes. Yale University Press, New Haven, CT

Klein Breteler WCM, Fransz HG, Gonzalez SR (1982) Growth and development of four calanoid copepod species under experimental and natural conditions. Neth J Sea Res 16: 195-207

Lam RK, Frost BW (1976) Model of copepod filtering response to changes in size and concentration of food. Limnol Oceanogr 21:490-500

Landry MR, Hassett RP (1982) Estimating the grazing impact of marine microzooplankton. Mar Biol 67:283-288

Lawrence D, Valiela I, Tomasky G (2004) Estuarine calanoid copepod abundance in relation to season, salinity, and land-derived nitrogen loading, Waquoit Bay, MA. Estuar Coast Shelf Sci 61:547-557

Lehman JT (1976) The filter-feeder as an optimal forager, and the predicted shapes of feeding curves. Limnol Oceanogr 21:501-516

Llope M, Anadón R, Viesca L, Quevedo M, González-Quirós R, Stenseth N (2006) Hydrography of the southern Bay of Biscay shelf-break region: integrating the multi-scale physical variability over the period 1993-2003. J Geophys Res 111:C09021

Lonsdale DJ, Cosper EM, Doall M (1996) Effects of zooplankton grazing on phytoplankton size-structure and biomass in the lower Hudson river estuary. Estuaries 19:874-889

López E, Anadón R, Harris RP (2007) Functional responses of copepod nauplii using a high efficiency gut fluorescence technique. Mar Biol 150:893-903 
López-Urrutia A, Irigoien X, Acuña JL, Harris R (2003) In situ feeding physiology and grazing impact of the appendicularian community in temperate waters. Mar Ecol Prog Ser 252:125-141

Lucic D, Njire J, Morovic M, Precali R, Fuks D, Bolotin J (2003) Microzooplankton in the open waters of the northern Adriatic Sea from 1990 to 1993: the importance of copepod nauplii densities. Helgol Mar Res 57:73-81

Mackas D, Bohrer R (1976) Fluorescence analysis of zooplankton gut contents and an investigation of diel feeding patterns. J Exp Mar Biol Ecol 25:77-85

Mauchline J (1998) The biology of calanoid copepods. In: Blaxter JHS, Southward AJ, Tyler PA (eds) Advanced marine biology. Academic Press, London

Micheli F (1999) Eutrophication, fisheries, and consumerresource dynamics in marine pelagic ecosystems. Science 285:1396-1398

Paffenhöfer GA (1971) Grazing and ingestion rates of nauplii, copepodites and adults of the marine planktonic copepod Calanus helgolandicus. Mar Biol 11:286-298

Paffenhöfer GA (1993) On the ecology of marine cyclopoid copepods (Crustacea, Copepoda). J Plankton Res 15: 185-211

Pedersen SA, Ribergaard MH, Simonsen CS (2005) Microand mesozooplankton in Southwest Greenland waters in relation to environmental factors. J Mar Syst 56:85-112

Quevedo M, Anadón R (2000) Spring microzooplankton composition, biomass and potential grazing in the Central Cantabrian coast (Southern Bay of Biscay). Oceanol Acta 23:297-310

Roff JC, Turner JT, Webber MK, Hopcroft RR (1995) Bacterivory by tropical copepod nauplii: extent and possible significance. Aquat Microb Ecol 9:165-175

Rothhaupt KO (1990) Changes of the functional responses of the rotifers Brachionus rubens and Brachionus calyciflorus with particle sizes. Limnol Oceanogr 35:24-32

Saiz E, Calbet A, Irigoien X, Alcaraz M (1999) Copepod egg production in the western Mediterranean: response to food availability in oligotrophic environments. Mar Ecol Prog Ser 187:179-189

Sommer F, Stibor H, Sommer U, Velimirov B (2000) Grazing by mesozooplankton from Kiel Bight, Baltic Sea, on different sized algae and natural seston size fractions. Mar Ecol Prog Ser 199:43-53

Editorial responsibility: Matthias Seaman (Assistant Editor-in-Chief), Oldendorf/Luhe, Germany
Stenseth NC, Llope M, Anadón R, Cianelli L, Chan KS and others (2006) Seasonal plankton dynamics along a crossshelf gradient. Proc R Soc B Biol Sci 273(1603):2831-2838

Sündermann J, Beddig S, Huthnance J, Mooers CNK (2001) Impact of climate change on the coastal zone: discussion and conclusions. Clim Res 18:1-3

Tackx MLM, Bakker C, van Rijswijk P (1990) Zooplankton grazing pressure in the Osterschelde (The Netherlands). Neth J Sea Res 25:405-415

Taylor AH, Geider RJ, Gilbert FJH (1997) Seasonal and latitudinal dependencies of phytoplankton carbon-to-chlorophyll a ratios: results of a modelling study. Mar Ecol Prog Ser 152:51-66

Torres CG, Escribano R (2003) Growth and development of Calanus chilensis nauplii reared under laboratory conditions: testing the effects of temperature and food resources. J Exp Mar Biol Ecol 294:81-99

Turner JT (2004) The importance of small planktonic copepods and their roles in pelagic marine food webs. Zool Stud 43:255-266

Turner JT, Tester PA (1992) Zooplankton feeding ecology: bacterivory by metazoan microzooplankton. J Exp Mar Biol Ecol 160:149-167

Turner JT, Levinsen H, Nielsen TG, Hansen BW (2001) Zooplankton feeding ecology: grazing on phytoplankton and predation on protozoans by copepod and barnacle nauplii in Disko Bay, West Greenland. Mar Ecol Prog Ser 221: 209-219

Uchima M, Hirano R (1986) Food of Oithona davisae (Copepoda: Cyclopoida) and effect of food concentration at first feeding on the larval growth. Bull Plankton Soc Jpn 33: $21-28$

Uitto A (1996) Summertime herbivory of coastal mesozooplankton and metazoan microplankton in the northern Baltic. Mar Ecol Prog Ser 132:47-56

Uye SI, Nagano N, Tamaki H (1996) Geographical and seasonal variations in abundance, biomass and estimated production rates of microzooplankton in the Inland Sea of Japan. J Oceanogr 52:689-703

White JR, Roman MR (1992) Seasonal study of grazing by metazoan zooplankton in the mesohaline Chesapeake Bay. Mar Ecol Prog Ser 86:251-261

Yentsch CS, Menzel DW (1963) A method for the determination of phytoplankton chlorophyll and phaeophytin by fluorescence. Deep-Sea Res 10:221-231

Submitted: September 25, 2006; Accepted: June 19, 2007 Proofs received from author(s): October 10, 2007 